\title{
Kiprah Muhammadiyah Dalam Pembaharuan Pendidikan dan Sosial Keagamaan di Nusantara: Kajian Terhadap Pemikiran KH. Ahmad Dahlan
}

\author{
Sutarto \\ Institut Agama Islam Negeri (IAIN) Curup \\ sutarto@iaincurup.ac.id \\ Dewi Pernama Sari \\ Institut Agama Islam Negeri (IAIN) Curup \\ fatiya.dewi@gmail.com \\ Anrial \\ Institut Agama Islam Negeri (IAIN) Curup \\ anrial@gmail.com
}

\begin{abstract}
This paper aims to discuss the progress of Muhammadiyah in the renewal of religious education and socioreligion in the archipelago, which includes the beginning of the renewal of education, philosophy, paradigms and objectives in educational renewal as well as the basic principles and guidelines for the social and religious renewal of Muhammadiyah. The method used is the Resarch library and analyzed with the reflective thinking approach by combining the deductive and inductive approaches. The results of the discussion showed that the concept of educational renewal developed by Muhammadiyah was modern-theocentric, namely modern education based on the divine values. In the socioreligious field Muhammadiyah invites Muslims to always do fastabiqul khairat, which is competing to do good in all aspects of life, both economics, health, congregation and so on.
\end{abstract}

Keywords: Muhammadiyah, Educational Renewal, Religious Social

Abstrak: Tulisan ini bertujuan untuk membahas tentang kiprah Muhamadiyah dalam pembaharuan pendidikan dan sosial keagamaan di Nusantara, yang mencakup awal mula pembaharuan pendidikan, falsafah, paradigma dan tujuan dalam pembaharuan pendidikan serta prinsip dasar dan tuntunan pembaharuan sosial keagamaan Muhammadiyah. Metode yang digunakan adalah library resarch dan 
2 | Belajea: Jurnal Pendidikan Islam, Vol. 5, No. 01, 2020

dianalisis dengan pendekatan reflektif thinking dengan memadukan pendekatan deduktif dan induktif. Hasil pembahasan menunjukan bahwa Konsep pembaharuan pendidikan yang dikembangkan oleh Muhammadiyah bersifat modern-theosentris, yatu pendidikan modern berbasis nikai-nilai ketuhanan. Di bidang sosial keagamaan Muhammadiyah mengajak umat Islam senantiasa melakukan fastabiqul khairat, yaitu berlomba melakukan kebaikan dalam semua aspek kehidupan, baik ekonomi, kesehatan, kesejarteraan umat dan sebaginya.

Kata Kunci: Muhammadiyah, Pembaharuan Pendidikan, Sosial Keagamaan

\section{Pendahuluan}

Muhammadiyah merupakan salah satu organisasi Islam terbesar di Indonesia yang memiliki peran sangat penting dalam perkembagan dakwah, pendidikan dan sosial kemasyarakatan. Secara historis, lahirnya organisasi ini bertujuan untuk membebaskan umat Islam dari berbagai praktek yang menyimpang dari ajaran Islam dan dari kebekuan disegala aspek kehidupan. ${ }^{1}$ Masyarakat Islam pada waktu itu, baik dalam kehidupan beragama dan pendidikan sangat dipengaruhi sikap fanatisme, bid'ah, khurafat dan konservatisme. Kondisi ini diperburuk dengan adanya kolonialisme dan misi kristenisasi. Akibatnya adalah umat Islam semakin terbelenggu oleh fahamfaham yang tidak selaras dengan prinsip dasar ajaran Islam.

Dilihat dari kacamata pendidikan, lahirnya Muhammadiyah salah satu diantaranya disebabkan adanya dualisme sistem pendidikan. Pertama, adanya sistem pendidikan kolonial (pendidikan Belanda) yang bersifat skuralistik dan diskriminatif. Dikatakan skuralistik karena pendidikan yang dilaksanakan oleh kolonial hanya mengkaji pengetahuan umum, dan mengenyampingkan pengetahuan agama. Pendidikan yang dilaksanakan oleh kolonial Belanda juga bersifat diskriminatif. Artinya tidak semua orang dapat mengikuti pendidikan yang dilaksanakan oleh sekolah-sekolah kolonial. Walaupun demikian, sisitem pendidikan yang dikelola oleh kolonia bersifat modern.

\footnotetext{
${ }^{1}$ Huda, S, "Teologi Mustad'afin di Indonesia: Kajian atas Teologi Muhammadiyah," TSAQAFAH 7(2) (2011). hlm. 345-374
} 
Kedua, pendidikan yang diselenggarakan oleh pribumi melalui pondokpondok pesantren dikelola secara tradisional dengan kurikulum seadanya. Pendidikan tradisional hanya mempelajarai tentang pelajaran agama, dikelola secara individu oleh guru atau kiyai, dan menggunakan metode srogan dan wetonan. Aktifitas pembelajaran bersifat pasif, siswa hanya menerima dan mencatat tanpa pertanyaan, mempertanyakan penjelasan sang kiyai kala itu merupakan sesuatu yang sangat tabu.

Dilihat dari segi pengelolaan dan cara mengajar, kedua sistem pendidikan tersebut, memiliki perbedaan yang sangat siknifikan. Pendidikan yang dikelola dengan sistem pendidikan kolonial (tipe pertama) menghasilkan lulusan yang kreatif, dinamis, dan percaya diri, namun tidak memahami ajaran agama, bahkan cenderung memandang negatif terhadap agama. Sementara tipe pendidikan kedua (sistem tradisional), melahirkan lulusan yang terisolasi dengan kehidupan modern dan cenderung mlinder, namun memiliki pemahaman dan ketaatan dalam menjalankan ajaran agama.

Atas dasar itulah, kemudian K.H. Ahmad Dahlan mendirikan sekolah di bawah naungan Muhammadiyah yang mencoba mengabungkan sisi positif dari sistem pendidikan kolonial dan tradisional. Dengan pengabungan kedua sistem tersebut, diharapkan dapat melahirkan manusia dalam sosok baru, yaitu ulama berkarakter intelek atau intelek berkarakter ulama. Dengan kata lain, Muhammadiyah melalui misi pendidikannya berupaya mencetak umat yang teguh keimanannya, luas dan mendalam pemahaman keagamaan serta memiliki keahlian di bidang lainnya, seperti politik, ekonomi, kesehatan dan sebagainya.

Untuk mewujudkan gagasannya, K.H. Ahmad Dahlan melakukan mewajibkan pendidikan agama di sekolah Belanda yang skuler, Azyumardi Azra mengistilahkan Sekolah umum (Belanda) plus, ${ }^{2}$ dan mendirikan sekolah di mana pelajaran umum dan agama diajarkan secara bersama-sama. Dalam hal lain, Muhammadiyah juga bereksprimen dengan mendirikan madrasah yang bersifat modern. Hal ini terlihat dengan didirikannya Madrasah Mu'alimin dan Madrasah Múalimah. Kedua madrasah ini diselenggarakan dengan sistem dan kelembagaan seperti sekolah. Madrasah yang dikembangkan Muhammadiyah tidak memakai sistem dan kelembagaan yang bersifat tradisional, seperti surau, pesantren

${ }^{2}$ Azumardi Azra, Pendidikan Islam: Tradisi dan Moderniasai di Tengah Melinim III (Jakarta: UIN Press, 2012). hlm. 36 
4 | Belajea: Jurnal Pendidikan Islam, Vol. 5, No. 01, 2020

sebagai, ${ }^{3}$ melainkan menggunakan sistem dan kelembagaan modern seperti yang dikembangkan oleh sekolah kolonial. Di bidang sosial keagamaan, Muhammadiyah juga gencar melakukan gerakan dalam rangka untuk mensejahterakan umat.

Kajian tentang kiprah Muhammadiyah sudah banyak dibahas oleh peneliti terdahulu namun memiliki penekanan pada aspek berbeda-beda. Di antara kajian tersebut adalah Fitriah. S membahas kiprah Muhammadiyah terhadap Pendidikannya di Gersik tahun 1026-1941. ${ }^{4}$ Mustapa, L. memfokuskan tentang teologi sosial KH. Ahmad Dahlan dalam pembaruan pendidikan Islam. ${ }^{5}$ Syarif Umar mencoba membandingkan pembaharuan pendidikan Islam antara Syekh Ahmad Surkatiy Dan Kh Ahmad Dahlan. ${ }^{6}$ Abidin, Z. membandingkan pemikiran pendidikan Muhammadiyah dan Nahdlatul Ulama. ${ }^{7}$ Sumarno, S. membahas pemikiran KH. Ahmad Dahlam tentang pembaharuan pendidikan Islam di Indonesia. ${ }^{8}$

Dari beberapa tulisan terdahulu sebagaimana dikemukakan di atas, memiliki penekanan yang bebeda-beda. Tulisan ini akan membahas kiprah Muhammadiyah dalam pembaharuan pendidikan dan sosial keagamaan di Nusantara khususnya terkait dengan pemikiran KH. Ahmad Dahlan. Fokus kaijan tulisan ini adalah tentang awal mula pembaharuan pendidikan Muhamadiyah, falsafah, paradikma, tujuan pembaharuan pendidikan dan sosial keagamaan Muhammadiyah.

Metode yang digunakan adalah library research dengan teknik study dokumentasi. Maksudnya adalah dalam membahas dan menguraikan topik di atas, penulis mengumpulkan data dari karya ilmiah, jurnal, buku dan sebagainya.

\footnotetext{
${ }^{3}$ Azumardi Azra. Pendidikan Islam: Tradisi dan Moderniasai di Tengah Melinim III hlm. 36

${ }^{4}$ FITRIANAH,S. (2015). Kiprah Muhammadiyah Terhadap Pendidikannya Di Gresik Tahun 1926-1942 (Doctoral dissertation, UNIVERSITAS AIRLANGGA).

${ }^{5}$ Mustapa, L. (2017). Pembaruan Pendidikan Islam: Studi atas Teologi Sosial Pemikiran KH Ahmad Dahlan. Jurnal Ilmiah AL-Jauhari: Jurnal Studi Islam dan Interdisipliner, 2(1), 90-111.

${ }^{6}$ Syarif, U. (2017). Gerakan Pembaruan Pendidikan Islam: Studi Komparasi Pergerakan Islam Indonesia Antara Syekh Ahmad Surkatiy Dan Kh Ahmad Dahlan. Reflektika, 12(1), 74-95.

${ }^{7}$ Abidin, Z. Menapaki Distingsi Geneologis Pemikiran Pendidikan (Muhammadiyah Dan Nahdlatul Ulama) Zainal Abidin Sekolah Tinggi Agama Islam Negeri (Stain) Jurai Siwo Metro. Nizham Journal of Islamic Studies, 4(2), 263-286.

${ }^{8}$ Sumarno, S. (2017). Pembaharuan Pendidikan Islam di Indonesia (Studi Pemikiran KH Ahmad Dahlan). AL-MURABBI: Jurnal Studi Kependidikan dan Keislaman, 3(2), 227-251.
} 
Data yang terkumpul dari beberapa literatu dianalisis dengan pendekatan reflektif thinking. Pendekatan ini berupaya menganalisis, membandingkan dan merefleksikan pemikiran, pendapat atau tulisan peneliti terdahulu yang berkaitan dengan topik yang dibahas. Hasil dari reflektif thinking tersebut dinarasikan dengan memadukan pendekatan deduktif dan induktif.

\section{Pembahasan}

\section{A. KH. Ahmad Dahlan dan Lahirnya Muhammadiyah}

Berbicara tentang Muhammadiyah tidak bisa dilepaskan dari K.H. Ahmad Dahlan, sebab beliau merupakan pendiri Muhammadiyah. K.H. Ahmad Dahlan lahir di Kauman Yogyakarta tahun 1869 . Nama kecilnya adalah Muhammad Darwisy. Ayahnya bernama K.H. Abu Bakar (seorang ulama dan khatib terkemuka di Mesjid Besar Kesultanan Yogyakarta). Ibunya merupakan putri dari H. Ibrahim (penghulu kesultanan Yogyakarta). ${ }^{9}$ K.H. Ahmad Dahlan merupakan anak keempat dari tujuh bersudara. Saudaranya semuanya perempuan, kecuali yang bungsu. Dilihat dari silsilahnya, ia merupakan keturunan keduabelas dari maulana Malik Ibrahim, salah seorang wali di antara Wali Songo yang terkenal sebagai tokoh yang menyebarkan dan mengembangkan Islam di tanah Jawa. ${ }^{10}$ K.H. Ahmad Dahan dikenal sederhana, mempunyai sikap kritis dan gigih dalam mempelajari ilmu-ilmu agama. Dalam belajar ilmu agama sering kali berpindah tempat, dari sekolah yang satu ke sekolah lainnya.

Di lihat dari pendidikan formalnya, waktunya banyak dihabiskan untuk mempelajari ilmu-ilmu agama dari pendidikan tradisiona. Namun sekitar tahun 1890 K.H. Ahmad Dahlan memperoleh kesempatan melanjutkan pendidikan di Mekeh. ${ }^{11}$ Di Mekah ia berinteraksi dengan beberapa tokoh modernisasi dunia Islam, seperti Muhammad Abduh, al-Afgani, Rasyid Ridha, dan Ibnu Taimiyah. ${ }^{12}$

\footnotetext{
${ }^{9}$ Deliar Noer, Gerakan Moderen Islam di Indonesia 1900-1942 (Jakarta: LP3ES, 2014). hlm. 84

${ }^{10}$ Mustapa, L, "Pembaruan Pendidikan Islam: Studi atas Teologi Sosial Pemikiran KH Ahmad Dahlan. Jurnal Ilmiah AL-Jauhari," Jurnal Ilmiah AL-Jauhari: Jurnal Studi Islam dan Interdisipliner 2(1) (2017). hlm. 90-111

${ }^{11}$ Musthafa Kamal Pasha dan Ahmad Adaby Darban, Muhammadiyah sebagai Gerakan Islam (Yogyakarta: LIPPI UMY, 2002). hlm. 8-9

${ }^{12}$ Arlen, D., Sudjarwo, S., \& Sinaga, R. M, "Pemikiran Kh. Ahmad Dahlan dalam Bidang Sosial dan Pendidikan,” Jurnal Studi Sosial 2(4) (2014).
} 
6| Belajea: Jurnal Pendidikan Islam, Vol. 5, No. 01, 2020

K.H Ahmad Dahlan juga pernah belajar dengan Syaikh Ahmad Khatib (18991916), ${ }^{13}$ dan Syeikh Djamil Djambek, ulama terkemuka dari Bukittinggi yang memilki wawasan modern dan berreputasi. ${ }^{14}$ Corak pemikiran tokoh-tokoh inilah yang mempengaruhi jiwa dan pemikirannya serta memotivasinya untuk melakukan perubahan pemahaman keagamaan khususnya di Indonesia dengan gagasan mengembalikan umat Islam ke ajaran Islam yang terdapat di dalam alQur'an dan Sunnah melalaui organisasi Muhammadiyah.

Pada tahun 1905 K.H. ahmad Dahlam kembali ke Indonesia, ${ }^{15}$ dan menikah dengan Siti Walidah, puteri seorang hakim di Yogyakarta. Siti Walidah merupakan pahlawan nasional dan pendiri Aisyiyah, oleh karena itu ia lebih dikenal dengan nama Nyai Ahmad Dahlan. Untuk memenuhi kebutuhan seharihari, K.H. Ahmad Dahlan berdagang batik dan keliling hampir ke semua daerah di Jawa sekali gus menyampaikan ide-idenya kepada umat Islam, khusunya yang menjadi tokoh di daerahnya masing-masing. Tokoh umat Islam yang sudah sepaham dengan Ahmad Dahlan inilah kemudian menjadi pengikutnya dan menjadi bagian terpenting dalam gerakan Muhammadiyah. ${ }^{16}$

Deliar Noer menjelaskan, pada awalnya Ahmad Dahlan dalam menyampaikan ide pembaharuan itu secara perorangan tetapi hal itu gagal. Hal ini terbukti ketika Ahmad Dahlan gagal dalam melakukan perubahan kiblat di masjid Sultan Yogyakarta yang ia anggap tidak tepat. Kemudian ia mendirikan langgar sendiri dengan melatakkan arah kiblat yang benar, tetapi hal itu tidak disukai oleh K.H. Mohammad Halil (penghulu), kemudian langgar tersebut dihancurkan. Dahlan patah hati, dan bahkan ingin pergi dari kota tempat lahirannya. Namun keluarganya tidak membolehkan dan membangunkan langgar lain, dan memberi jaminan bahwa ia dapat mengajar dan mempraktekkan agama menurut yang ia yakini. ${ }^{17}$

${ }^{13}$ Muhammad Syamsu As, Ulama Pembawa Islam di Indonesia dan Sekitarnya (Jakarta: Lentera, 2017). hlm. 245

${ }^{14}$ Maunah, H. B. (2016). Sejarah pemikiran dan tokoh modernisme Islam. (Jakarta: PT. Raja Grafindo Persada, 2016). hlm. 128

${ }^{15}$ Ahmat Tufik, dkk, Sejarah Pemikiran dan Tokoh Modernisme Islam (Jakarta: Raja Grafindo Persada, 2005). 129

${ }^{16}$ Muttaqin, A. (2017). Pemikiran pembaharuan Pendidikan Islam: Studi komparasi atas pemikiran KH. Hasyim Asy'ari dan KH. Ahmad Dahlan, implementasinya dalam Pendidikan Islam di Era Global (Doctoral dissertation, Universitas Islam Negeri Maulana Malik Ibrahim). 102

${ }^{17}$ Deliar Noer, Gerakan Moderen Islam di Indonesia 1900-1942. hlm. 85 
Sebelum mendirikan Muhammadiyah, K.H. Ahmad Dahlan pernah bergabung dengan Jam'iyatul Khair, ${ }^{18}$ Budi Utomo, ${ }^{19}$ Sarekat Islam. Kemudian pada tanggal 18 November 1912 tepatnya di Yogyakarta lahirlah Muhammadiyah sebagai gerakan umat Islam di bidang sosial dan pendidikan. ${ }^{20}$ Berdirinya Muhammadiyah awalnya direspon secara negatif, baik dari keluarganya sendiri maupun dari masyarakat sekitarnya. ${ }^{21}$ Akibatnya fitnahan, hasutan dan tuduhan datang silih berganti. Tuduhan mendirikan agama baru, kiai palsu, meniru budaya Belanda dan agama Kristen datang secara bertubi-tubi. Bahkan ancaman pembunuhan pun datang menghampirinya. ${ }^{22}$

Berbagai rintangan yang datang dihadapi dengan sabar. Hatinya tetap teguh melanjutkan cita-cita dan perjuangannya melakukan pembaharuan pemahaman terhadap Islam di Indonesia. Pada tanggal 23 Februari 1923 dalam usia 55 tahun, saat Muhammadiayah sudah mulai kuat dan mendapatkan dukungan dari Umat Isalam, K.H. Ahmad Dahlan wafar. Walaupun demikian, gerakan Muhammadiyah tetap berjalan dan berkembang secara pesat di seluruh Indonesia dengan segala bentuk amal usahanya baik di bidang keagamaan, pendidikan, kesehatan, sosial kemasyarakatan dan sebagainya.

Muhammadiyah merupakan salah satu organisasi sosial dan kemasyarakatan Islam memiliki peran yang sangat penting dari masa sebelum penag dunia ke II sampai saat saat ini. Di lihat dari sejalah kelahirannya, Muhammadiyah tidak bisa dilepaskan dari Kauman di Kelurahan Ngupasan, Kecamatan Gondomanan, Kota Yogyakarta atau sekitar 500 meter sebelah selatan Malioboro. Pada 8 Dzulhijjah 1330, bersamaan 18 November 1912 di tempat inilah K.H. Ahmad Dahlan atas saran beberapa orang anggota Budi

${ }^{18}$ Stepu, S. B. (2016). Pemikiran teologi KH Ahmad Dahlan (Doctoral dissertation, Universitas Islam Negeri Sumatera Utara). hlm. 160

${ }^{19}$ Deliar Noer, Gerakan Moderen Islam di Indonesia 1900-1942. hlm. 86

${ }^{20}$ Yusra, N. (2018). Muhammadiyah: Gerakan Pembaharuan Pendidikan Islam. POTENSIA: Jurnal Kependidikan Islam, 4(1), 103-125.

${ }^{21}$ Sejarah Hidup KH. Ahmad Dahlan: TOKOH PENDIDIKAN DAN PEMIKIRANNYA (academia.edu, t.t.). hlm. 9

${ }^{22}$ Deliar Noer, Gerakan Moderen Islam di Indonesia 1900-1942. hlm. 90 
8 | Belajea: Jurnal Pendidikan Islam, Vol. 5, No. 01, 2020

Utomo mendirikan Muhammadiyah yang ditandai dengan didirikannya lembaga pendidikan yang bersifat permanen dan moderan. ${ }^{23}$

Lahirnya pemikiran modern melalui wadah organisasi Muhammadiyah pada awal abad 20, tidak bisa dipisahkan dengan keadaan politik dan sosial umat Islam saat itu. Secara politik, umat Islam dikuasi oleh kolonial Belanda, sedangkan secara sosial, umat Islam dalam menjalankan ritual keagamaan diselimuti oleh tradisi Hindu-Budha yang penuh dengan sinkretis. Sikap keberagamaan umat Islam bercampur dengan bid'ah, syirik, khurafat, taqlid buta, terjadinya proses Islamisasi yang bersifat mistis dan penduduk pribumi memiliki partisipasi yang sangat rendah dalam bidang pendidikan. ${ }^{24}$

Dari segi sistem pendidikan, penekanannya adalah mengaji bukan mengkaji. Akibatnya pemikiran yang bersifat kritis dan rasional kurang berkembang. Di sisi lain, sekolah-sekolah umum gencar memperkenalkan ilmuilmu dan budaya Barat yang diiring dengan kristenisasi dan westernisasi tanpa diimbangi dengan pendidikan agama. ${ }^{25}$ Lembaga pendidikan yang dikelola oleh uamt Islam tidak mampu mengikuti perkembangan zaman, akibatnya menjadi semakin terisolir dari pengaruh luar. Keadaan sosial, ekonomi, politik dan cultural semakin mengkuatirkan sebagi akibat dari penjajahan, ${ }^{26}$ juga turut mendorong lahirnya Muhammadiyah.

Lahirnya Muhammadiyah, selain adanya kesadaran dari pendirinya juga tidak terlepas dari dorongan tokoh Budi Utomo agar Ahmad Dahlan membentuk suatu organisasi guna menyebarkan ide dan gagasannya yang moderat. Tujuannya adalah agar ide dan gagasan serta sekolah yang didirikan tetap berkelanjutan ketika ia sudah tidak ada. Selain itu Ahmad Dahlan juga aktif dan belajar berorganisasi di Jami'at Khair yang merupakan salah satu organisasi modern kala itu. Dorongan dari Boedi Oetomo dan pengalaman berorganisasi menambah motivasi Ahmad Dahlan untuk mendirikan organisasi

${ }^{23}$ Basinun, B. (2018). MODERNISASI PENDIDIKAN ISLAM DI INDONESIA: RESPON MUHAMMADIYAH TERHADAP MODEL PENDIDIKAN BARAT. At-Ta'lim: Media Informasi Pendidikan Islam, 16(2), 255-275.

${ }^{24}$ Abuddin Nata (ed), Sejarah Pertumbuhan dan Perkembangan Lembaga-Lembaga Pendidikan Islam di Indonesia (Jakarta: Gramedia, 2016). hlm. 256

${ }^{25}$ Abuddin Nata (ed). Sejarah Pertumbuhan dan Perkembangan Lembaga-Lembaga Pendidikan Islam di Indonesi. hlm. 256

${ }^{26}$ Syaifuddin, M. A., Anggraeni, H., Khotimah, P. C., \& Mahfud, C. (2019). Sejarah Sosial Pendidikan Islam Modern Di Muhammadiyah. TADARUS, 8(1). 
Muhammadiyah yang berkembang sampai saat ini dan menjadi salah satu organisasi Islam terbesar di Indonesia bahkan di dunia. ${ }^{27}$

Sampai tahun 1917, Ahmad Dahlan beraktifitas sebagai guru di sekolah Muhammadiyah dan membimbing masyarakat tentang berbagai kegiatan keagamaan. Setelah tahun 1917, Muhammadiyah mulai menerima berbagai permintaan untuk mendirikan cabang di luar Yogyakarta. Pada tahun 1920 kegiatan Muhamadiyah meluas, meliputi kawasan pulau Jawa, dan berkembang ke wilayah Indonesia sekitar tahun $1921 .^{28}$

\section{B. Pembaharuan bidang pendidikan}

1. Awal mula pembaharuan pendidikan Muhammadiyah

Gerakan pembaharuan pendidikan yang dilaksanakan oleh Muhammadiyah lahir pada akhir abad 19. Gerakan ini lahir karena kolonial Belanda ketika itu melaksanakan sistem pendidikan liberal di Indonesia. Awalnya sistem pendidikan liberal ini hanya diperuntukkan bagi orang tertentu, namun sekitar tahun 1870 atau awal abad 20, sistem pendidikan liberal mulai diterapkan untuk kalangan luas termasuk bagi umat Islam. ${ }^{29}$

Di sisi lain, sistem pendidikan pada masa penjajahan Belanda, secara umum terdapat 4 model persekolahan belanda yaitu : Sekolah Eropa yang menampung anak keturunan Eropa, dan birokrat terkemuka. Sekolah Cina Belanda, yaitu sekolah yang menampung anak-anak timur asing, khususnya keturunan Cina. Sekolah Vernakuler, yaitu sekolah yang di desain untuk kepentimgan Belanda sendiri. Sekolah Pribumi, yaitu sekolah yang didirikan oleh lembaga agama dan di luar kendali Belanda. ${ }^{30}$

Sistem pendidikan tersebut memunculkan beberapa akibat, diantarnaya dalah: Petama, melahirkn jurang pemisah semakin besar kolonial Belanda dengan pribumi. Kedua, sistem pendidikan keagamaan yang dikelola oleh pribumi semakin tertinggal dan kontras dengan sistem didaktikpedagogis. Ketiga, penduduk pribumi yang sekolah di lembaga pendidikan

\footnotetext{
${ }^{27}$ Slamet Abdullah \& Muslich KS, Se-Abad Muhammadiyah, dalam Pergumulan Budaya Nusantara (Yogyakarta: Global Pustaka Utama, 2010). hlm. 3-4

${ }^{28}$ Sejarah Hidup KH. Ahmad Dahlan: TOKOH PENDIDIKAN DAN PEMIKIRANNYA.

${ }^{29}$ Karel A. Steenbrink, Pesantren, Madrasah, Sekolah: Pendidikan Islam dalam Kurun Moderen (Jakarta: LP3ES, 1994). hlm. 23

${ }^{30}$ Afifuddin, Sejarah Pendidikan, (Bandung: Prosfect, 2017). hlm. 36-37
} hlm. 10 
10 | Belajea: Jurnal Pendidikan Islam, Vol. 5, No. 01, 2020

Belanda kurang memiliki pemahaman agama. ${ }^{31}$ Menghadapi realitas tersebut, Ahmad Dahalan mencoba memadukan dua sistem pendidikan yang ada. Upaya tersebut diawali dengan mengidentifikasi masalah yang di hadapi umat Islam yang perlu dicarikan solusinya melalui bidang pendidikan. Kemudian dicarikan jawaban dan disosialisaikan kepada keluarga dan sahabat terdekat melalui kegiatan pengajian. Setelah dianggap berhasil. kemudian dibentuk wadah untuk yang bernama "Pergerakan Muhammadiyah". 32

Dalam melaksanakan proses pendidikan, Ahmad Dahlan menerapkan metode induktif, ilmiah, naqliah dan Tanya jawab. Metode ini berbeda dengan wetonan atau bandongan dan sorogan yang diterapkan di lembaga pendidikan agama tradisional kala itu. Metode wetonan atau bandongan adalah metode pengajaran di mana sang guru atau kiyai hanya membaca dan menjabarkan isi kandungan kitab kuning, santri hanya menyimak dan mendengarkan. Sedangkan metode sorogan merupakan metode pengajaran dimana santri membaca kitab, sementara kiyai atau guru mendengarkan sambil membetulkan dan meberikan bimbingan dan komentar yang diperlukan. ${ }^{33}$

Langkah awal pembaharuan pendidikan yang dilakukan oleh Muhammadiyah dengan menyelenggarakan pengajian keagamaan dan mendirikan lembaga pendidikan. Pada tahun 1918 berdiri sekolah "al-Qim al-Arqa", dua tahun berikutnya berdiri pondok muhammadiyah di Kauman. ${ }^{34}$ Selama tahun 1923 Muhammadiyah sudah berhasil mendirikan 5 jenis sekolah, yang terdiri dari 32 Volkschool (sekolah dasar lima tahun), 8 sekolah Hollands Inlandse School (HIS), 1 Schakelschool (Sekolah 5 tahun untuk menyambung ke MULO), 14 Madrasah dan 1 sekolah pendidikan guru, ${ }^{35}$

${ }^{31}$ Afifuddin. hlm. 38-39

${ }^{32}$ Afifuddin. hlm. 40

${ }^{33}$ Lenggono, W. (2018). Lembaga Pendidikan Muhammadiyah (Telaah Pemikiran KH Ahmad Dahlan tentang Pembaruan Pendidikan Islam di Indonesia). Islamadina: Jurnal Pemikiran Islam, 19(1), 43-62.

${ }^{34}$ Slamet Abdullah \& Muslich KS. Se-Abad Muhammadiyah, dalam Pergumulan Budaya Nusantara. hlm. 42

${ }^{35}$ Karel A. Steenbrink, Pesantren, Madrasah, Sekolah: Pendidikan Islam dalam Kurun Moderen. hlm. 54 
dengan 4.000 murid dan 119 guru. ${ }^{36}$ Selain itu, Muhammadiyah juga mendirikan sekolah agama seperti Madrasah Diniyah di Minangkabau. Pada tanggal 8 Desember 1921 didirikan Pondok Muhammadiyah yang merupakan sekolah khusus untuk guru agama. ${ }^{37}$

Untuk memajukan pendidikan, Muhammadiyah bersifat koperatif dan mau menerima sibsidi keuangan dari kolonial Belanda, walaupun jumlahnya sangat sedikit dan tidak sebanding dengan dana yang diberikan kepada sekolah-sekolah Kristen kala itu. Sikap Muhammadiyah ini mendapat kritikan tajang dari Taman Siswa dan Syarikat Islam. Namun Muhammadiyah beralasan, subsidi pendidikan yang diberikan kolonial berasal dari pajak yang diperas kolonial dari pribumi khususnya umat Islam dan tidak ada salahnya jika subsidi tersebut digunakan untuk memajukan pendidikan masyarakat. Jika menolak maka maka subsidi tersebut akan dialihkan ke sekolah-sekolah Kristen. ${ }^{38}$

Perkembangan pendidikan Muhammadiyah sangat pesat, pada akhir tahun 1932 Muhammadiyah telah memiliki 103 Volkschool (Sekolah Dasar 5 tahun), 47 Standaardschool (Sekolah dasar 6 tahun), 69 Hollands inlands School (HIS) dan 25 Schakelschool, yaitu sekolah 5 tahun yang akan menyambung ke MULO (Meer Uitgebreid Leger Ondewnijs) setingkat SMP. Pada waktu itu, sekolah-sekolah yang didirikan oleh Muhammadiyah memiliki persyaratan dan kurikulum yang sama dengan sekolah-sekolah Belanda, yang membedakannya adalah memasukkan pendidikan agama sebagai kurikulum wajib, atau dengan dengan istilah memasukkan pendidikan mede in Qur'an ke dalam kurikulum. ${ }^{39}$ Di sekolah Muhammadiyah selain menggunakan bahasa daerah dan bahas Indonesia, juga memakai bahasa Belanda sebagai bahasa pengantar. Sekolah-sekolah Muhammadiyah ketika itu berkembang pesat dan mampu menyaingi sekolah-sekolah Belanda, Katolik dan Protestan. ${ }^{40}$

${ }^{36}$ Abuddin Nata (ed), Sejarah Pertumbuhan dan Perkembangan Lembaga-Lembaga Pendidikan Islam di Indonesia. hlm. 259

${ }^{37}$ Karel A. Steenbrink, Pesantren, Madrasah, Sekolah: Pendidikan Islam dalam Kurun Moderen. hlm. 55

${ }^{38}$ Azumardi Azra, Pendidikan Islam: Tradisi dan Moderniasai di Tengah Meliniu III. hlm. 36

${ }^{39}$ Azumardi Azra. hlm. 36

${ }^{40}$ Azumardi Azra. hlm. 37 
12 | Belajea: Jurnal Pendidikan Islam, Vol. 5, No. 01, 2020

Dalam usianya yang lebih satu abad, Muhammadiyah tetap progresif dan konsisten dalam mencerdaskan anak bangsa melalui pendidikan. Muhammadiyah banyak memiliki sekolah mulai dari Taman Kanak-kanak (TK) sampai perguruan tinggi bahkan smapai ke program Doktor (S3). Data tahun 2005 menunjukkan Muhammadiyah memiliki Taman KanakKanak (TK) sebanyak 4.975, SD/SMP Islam 1.332, Pesantren 64, MUalimin/Mualimat 13, ${ }^{41}$ Sekolah Dasar (SD) 1.128, Madrasah Ibtida'iyyah (MI) 1.768, Sekolah Menengah Pertama (SMP) 1.179, Madrasah Tsanawiyah (MTs) 534, Sekolah Menengah Atas (SMA) 509, Sekolah Menengah Kejuruan (SMK) 249, Madrasah Aliyah (MA) 171, dan jumlah perguruan tinggi Muhammadiyah (PTM) adalah 182. ${ }^{42}$

Geertz menjelaskan, program pendidikan yang dilaksanakan oleh Muhammadiyah adalah sistem pembelajaran berpolakan sistem sekolah negeri. Sistem ini dibuat dalam rangka untuk mensejajarkan sistem pendidikan swasta dengan sistem nasional. ${ }^{43}$ Dilihat secara histori, awal lahirnya sistem pendiikan Muhammadiyah cenderung menyesuaikan dengan pendidikan kolonial, walaupun hanya sebatas tata cara pelaksnaan, bukan dalam tataran tujuan dan materi atau isi pendidikan, ${ }^{44}$ dengan kata lain suatu gerakan yang bersifat akomodatif.

Pembaharuan pendidikan yang dilakukan Muhammadiyah pada masa kolonial diantaranya dilakukan dengan mendirikan lembaga-lembaga pendidikan. Secara umum lembaga pendidikan yang didirikan oleh Muhammadiyah dapat dikelompokkan menjadi dua. Pertama, sekolah agama Muallimin (untuk putra), Muallimat (untuk putri), Diniyah Ibtidaiyah (sekolah agama tingkat dasar 3 tahun), Diniyah Wustho (sekolah agama tingkat menengah), sekolah Tabligh (sekolah agama lanjutan atas), Kuliyatul Muballighin. Kedua, Sekolah Umum, sepeti Volks School Moehammadijah (sekolah dasar 3 tahun), Vervolg School (lanjutan dari Volks School), Normal School (sekolah guru setelah Vervolg), Cursus Voor Volks Onderwijzer (CVO),

${ }^{41}$ Rahem, Z, "Gerakan Progressif Muhammadiyah dan Nahdlatul Ulama Menjaga Marwah Pendidikan Keislaman di Nusantara," Al Hikmah: Jurnal Studi Keislaman 9(1) (2017).

42 Said Tuhuleley (ed), Reformasi Pendidikan Muhammadiyah Suatu Keniscayaan (Yogyakarta: SM, 2016). hlm. 29

${ }_{3}$ Abuddin Nata (ed), Sejarah Pertumbuhan dan Perkembangan Lembaga-Lembaga Pendidikan Islam di Indonesia. hlm. 262

${ }^{44}$ Abuddin Nata (ed). hlm. 262 
Hollandsch Inlandsche School (HIS), Schakel School, Meer Uitgebreid Lager Onderwijs (MULO), Algemeene Middlebare School (AMS), dan Hollandsch Inlandsche Kweekschool (HIK). ${ }^{45}$

Menurut Ramayulis, dilihat dari sudut historis, Muhammadiyah memiliki andil yang sangat besar dalam pembaharuan bidang pendidikan di Indonesia. Pembaharuan yang dilakukan Muhammadiyah diantaranya adalah modernisasi pesantren. Untuk mewujudkan hal ini, Muhammadiyah mendirikan Madrasah al Diniyah, yang khusus memberikan pelajaran agama, dan sekolah yang mengajarkan pelajaran agama dan pelajaran umum. Selain itu Muhammadiyah juga mendirikan sekolah model Belanda, seperti Holland Islandes School (HIS) dan Kweek School (Sekolah Guru), namun tetap menjadikan pendidikan agama sebagai salah satu kurikulum wajib. ${ }^{46}$

Dalam perkembangan selanjutnya, Muhammadiyah juga mendirikan sekolah-sekolah mirip pondok pesantren yang dikelola secara modern. Namun pada dasarnya semuanya itu dilakukan dalam rangka untuk mencerdaskan anak bangsa melalui jalur pendidikan yang disesuikan dengan kemajuan dan perkembangan zaman. Sekolah-sekolah yang diselenggarakan oleh Muhammadiyah dalam bentuk pondok pesantren di antaranya adalah pondok pesantren Muhammadiyah di Kampung Delima Kabupaten Reujang Lebong Propinsi Bengkulu, Pondok Pesantren Muhammadiyah Al Mumtar Kota Solok Sumatera Barat dan sebagainya.

Pembaharuan pendidikan yang dilakukan oleh Muhammadiyah secara umum dapat dikatakan bahwa, Pertama, Pembaharuan pendidikan yang dilakukan Muhammadiyah lahir ketika kondisi pendidikan umat memperihatinkan, terutama adanya pendangkalan nilai-nilai Islam yang dilakukan oleh penjajah melalui sisitem pendidikan yang bersifat sekuler. Kedua, cikal bakal Pendidikan Muahmadiyah diawali melalui pengajian yang bersifat sederhana yang dibimbing Ahmad Dahlan. Ketiga, cita-cita pembaruan dalam pendidikan dilakukan dengan sunguh-sungguh dan terus menerus baik melalui pengaiian maupun melalui lembaga pendidikan. Keempat, pendidikan yang dikelola Muhammadiyah bersifat moderantheosentris. Di satu sisi pendidikan yang dikelola oleh Muhammadiyah

${ }^{45}$ Ahmad Mansur Suryanegara, Api Sejarah (Bandung: Salamadina, 2010). hlm. 444

${ }^{46}$ Ramayulis, Sejarah Pendidikan Islam: Napaktilas Pembaharuan Konsep, Filsafat dan Metodologi Pendidikan Islam dari Era Nabi SAW sampai Ulama Nusantara (Jakarta: Kalam Mulia, 2016). hlm. 318-319 
14 | Belajea: Jurnal Pendidikan Islam, Vol. 5, No. 01, 2020

mengadopsi kurikulum, sistem dan metode pembelajaran dari sekolah Belanda, tetapi di sisi lain juga menjadikan pendidikan agama sebagai kurikulum wajib di sekolah. Pada proses selanjutnya, pendidikan Muhammadiyah ini berkembang dengan pesat, dari Taman Kanak-kanak (TK), sampai ke jenjang perguruan tinggi (S1, S2 dan S3).

2. Falsafah dan Paradigma Pendidikan Muhammadiyah

Ada beberapa aliran filsafat dalam filsafat pendidikan, diantaranya adalah esensialisme, progresivisme, dan rekonstruksi sosial. Aliran esensialisme memandang bahwa tugas utama pendidikan adalah untuk melestarikan budaya. Progresivisme perbedapat, tujuan utama pendidikan adalah untuk mengembangkan potensi peserta didik. Secara optimal. Aliran rekonstruksi sosial mengatakan, pendidikan pada dasarnya untuk melakukan perubahan baik secara individu maupun secara kolektif melalui suatu organisasi. ${ }^{47}$ Menurut Said Tuhuleley, secara eksplisit falsafah pendidikan yang diselenggarakan oleh Muhammadiyah masuk ke dalam perpaduan ketiga esensialisme atau perenialisme, progresivisme, sekaligus rekonstruksi sosial. $^{48}$

Amin Abdullah (dalam Said Tuhuleley) menjelaskan, ada empat paradigma pendidikan dalam presfektif Muhammadiyah. Pertama, pembaharuan yang bersifat kritis-hermeneutis. Muhammadiyah dalam misinya senantiasa menyerukan "kembali kepada al-Qur'an dan Sunnah". Seruan kembali kepada al Qur'an dan Sunnah diiringi dengan "ijtibad" dan "tajdid” berkaitan dengan masalah sosial keagamaan. Secara makna, "ijtihad" dan 'tajdid' dapat dibedakan, namun dalam implementasinya keduanya tidak dapat dipisahkan. Melalui ijtihad dan tajdid inilah, Muhammadiyah sengaja meniru dan melaksanakan sistem pendidikan "sekolah" (tidak menyebut sistem pendidikan Barat) yang dipadukan dengan ilmu agama. Pada akhirnya menghasilkan sistem baru, dimana ilmu pengetahuan diajarkan secara utuh dan komprehensif, baik dalam bidang sosial, eksak,

${ }^{47}$ Samsul Nizar dan Ramanyulis, Filsafat Pendidikan Islam (Jakarta: Kalam Mulia, 2016). hlm. 12-19

${ }^{48}$ Said Tuhuleley (ed), Reformasi Pendidikan Muhammadiyah Suatu Keniscayaan. hlm. 35-40 
ekonomi, budaya, dan science dengan tetap mempelajari dan mendalami ilmu agama. $^{49}$

Kedua, paradiga pembaharuan pendidikan bercorak esensialis sekaligus perennialis. Pemabaharuan pendidikan yang dilakukan oleh Muhammadiah menekankan pada nilai-nilai esensial yang terdapat di dalam al-Qur'an dan Sunnah yang harus dimalkan dalam pelaksanaan pendidikan secara mutlak. ${ }^{50}$ Ketiga, paradigma pembaharuan bercorak rekonstruksi sosial (social reconstruction). Unjuk mewujudkan ide dan gagasan di bidang pendidikan Muhammadiyah menggunakan sistem organisasi. Keempat, paradigma pembaharuan bercorak progressif. Pendidikan yang diselenggarakan oleh Muhammadiyah senantiasa berorientasi ke depan (future oriented). Oleh karena itu, dalam penyelenggaraan pendidikan, selalu dilakukan evaluasi, koreksi, perbaikan dan penyempurnaan cara berfikir dan cara kerja untuk meinglatkan mutu dan menghadapi tantangan di masa akan datang. ${ }^{51}$

Dari empat paradigma pembaharuan pendidikan Muhamadiyah sebagai mana dikemukakan di atas dapat dipahami bahwa, paradigma pendidikan Muhammadiyah pada dasarnya adalaha menyatukan ilmu atau kekuatan akal dengan wahyu. Wahyu (al Qur'an dan Sunnah) dijadikan acuan dasar. Dalam tataran operasional, umat harus menguasi berbagai sektor kehidupan dan bidang ilmu (keahlian) untuk memajuan bangsa dan negara, selama tidak bertentang dengan prinsip dasar yang terdapat di dalam al Qur'an dan Sunah.

3. Tujuan pendidikan Muhammadiyah

Pada masa awal berdirinya Muhammadiyah, tujuan pendidikan belum dirumuskan secara tegas. Hal ini bukan berarti, pendidikan yang didirikan oleh Muhammadiyah tidak memiliki arah dan tujuan. Walaupun belum dirumuskan secara tegas, pendidikan Muhammadiyah sejak awal sudah memiliki tujuan dan arah yang sangat jelas. Dari sistem pendidikan yang dikembangkan misalnya, tujuan utamanya adalah "Membentuk intelektual

\footnotetext{
${ }^{49}$ Nuris, A. (2017). Ahmad Dahlan Dan Pesantren: Gerakan Pembaharuan Pendidikan, Dakwah, Dan Pemberdayaan Masyarakat Di Indonesia. Dirosat: Journal of Islamic Studies, 1(2), 243-258.

${ }^{50}$ Said Tuhuleley (ed). hlm. 45

${ }^{51}$ Said Tuhuleley (ed). hlm. 49
} 
16 | Belajea: Jurnal Pendidikan Islam, Vol. 5, No. 01, 2020

yang 'alim", yaitu melahirkan lulusan yang memiliki ilmu pengetahuan yang luas dan memahami ilmu agama. Tujan Pendidikan Muhammadiyah dirumuskan dari pernyataan yang sering dikemukakan oleh Ahmad Dahlan kepada murid-muridnya dalam setiap pengajian yaitu: "dadiyo kyai sing kemajuan, lan ojo kesel-kesl anggonmu nyambut gawe kanggo Mubammadiyah" (jadilah ulama yang modern dan jangan merasa lelah bekerja untuk Muhammadiyah). ${ }^{52}$ Ulama modern yang dimaksud adalah ulama yang bukan hanya menguasai ilmu agama, tetapi juga menguasai dan ahli di bidang ilmu pengetahuan umum.

Tujuan pendidikan Muhammadiyah pada hakikatnya sudah tertuang di dalam Kaidah Pendidikan Dasar dan Menengah yang telah disahkan oleh Majlis Tanwir dan menjadi rujukan bagi perguruan Muhammadiyah. Tujuan tersebut tertuang Bab I pasal 3 sebagai berikut: "Pendidikan dasar dan menengah Muhammadiyah bertujuan: "membentuk manusia muslim yang beriman, bertaqwa berakhlaq mulia, cakap percaya dri, memajukan dan menembangkan ilmu pengetahuan dan ketereampilan dan beramal menuju terwujudnya masyarakat utama, adil dan makmur yang diridhai oleh Allah SWT..$^{53}$

Tujuan pendidikan Muhammadiyah, terdapat nilai fundamental yang secara implisit bersumber dari al-Qur'an dan Sunnah. Rumusan tujuan pendidikan Muhammadiyah diawali dengan menanamkan semangat juang untuk melakukan perubahan, kemudian diiringi dengan berbagai upaya untuk mengisi dan berperan aktif daalm membangun bansa dan negara. Ini berarti, secara implisist tujuan pendidikan Muhammadiyah bukan berorietnasi pada kadernya semata, tetapi untuk semua anak bangsa dalam upaya membangun manusia Indonesia seutuhnya, lahir dan batin seperti yang dicita-citakan seluruh bangsa Indonesia. ${ }^{54}$ Tujuan pendidikan

${ }^{52}$ Enung Rukiati dan Hikmawati Feti, Sejarah Pendidikan Islam di Indonesia (Bandung: Pustaka Setia, 2016). hlm. 43-45

53 Mayarisa, D. (2018). KONSEP INTEGRASI PENDIDIKAN ISLAM DALAM PERSPEKTIF PEMIKIRAN KH. AHMAD DAHLAN. FITRA, 2(1).

${ }^{54}$ Enung Rukiati dan Hikmawati Feti. hlm. 57 
Muhammadiyah pada dasarnya sejalan dengan tujuan pendidikan Republik Indonesia dan mendukung terwujudnya tujuan pendidikan R.I. ${ }^{55}$

\section{Gerakan Sosial Keagamaan Muhammadiyah}

Muhammadiyah sebagai gerakan sosial keagamaan perlu didukung oleh usaha ekonomi untuk memperkuat organisasi. Hubungan antara kiyai dengan kegiatan ekonomi kelihatan jelas di lingkungan Muhammadiyah dibandingkan organisasi sosial keagamaan lainnya. ${ }^{56} \mathrm{Hal}$ ini terlihat, selain menjadi khatib di masjid kesultanan Yogya, pendiri Muhammadiyah K.H. Ahmad Dahlan juga sebagai pengusaha batik untuk memenuhi kehidupan keluarganya. ${ }^{57}$ Dalam berMuhammadiyah, Ahmad Dahlan bersemboyan "Hidupilah Muhammadiyah, jangan mencari hidup dari Muhammadiyah". ${ }^{88}$ Hal ini menunjukkan bahwa prinsip dasar dalam melakukan gerakan sosial keagamaan yang diajarkan oleh Ahmad Dahlan bukan untuk mencari keuntungan, tetapi adalah untuk melakukan kebaikan.

Berkaitan dengan sosial keagamaan, Muhammadiyah menetapkan beberapa tuntunan. Tuntuna tersebut meliputi, tuntunan dalam berorganisasi, bermasyarakat, mengelolah amal usaha, berbisnis, mengembangkan profesi, berbangsa dan bernegara, melestarikan lingkungan, mengembangkan ilmu pengatahuan dan teknologi, serta tuntunan hidup bermasyarakat dalam ruang seni dan budaya. ${ }^{59}$

Prinsip utama dalam gerakan sosial keagamaan Muhammadiyah adalah menjalin persaudaraan dan kebaikan terhadap sesama, seperti keluarga dan tetangga, baik muslim maupun non muslim dengan tetap memelihara hak dan kehormatan. Berkaitan dengan hubungan sosial secara luas, setiap pengurus, anggota dan kader harus tetap menjunjung tinggi hak dan kehormatan manusia,

${ }^{55}$ Susiyani, A. S. (2017). Manajemen Boarding School dan Relevansinya dengan Tujuan Pendidikan Islam di Muhammadiyah Boarding School (MBS) Yogyakarta. Jurnal pendidikan madrasah, 2(2), 327-347.

${ }^{56}$ M. Dawam Raharjo, Intelektual Intelegensia dan Perilaku Politik Bangsa: Risalah Cendikiawan Muslim (Bandung: Mizan, 2016). hlm. 173

${ }^{57}$ Deliar Noer, Gerakan Moderen Islam di Indonesia 1900-1942. hlm. 253

58 M. Dawam Raharjo, Intelektual Intelegensia dan Perilaku Politik Bangsa: Risalah Cendikiawan Muslim. hlm. 173

${ }^{59}$ Pimpinan Pusat Muhammadiyah, Pedoman Hidup Islami Muhammadiyah (Keputusan Mukhtamar Muhammadiyah ke-44 tahun 2000 di Jakarta (Jakarta: Suara Muhammadiyah, 2012). hlm. xii 
18 | Belajea: Jurnal Pendidikan Islam, Vol. 5, No. 01, 2020

memupuk persatuan, persaudaraan, toreransi, adil, mencegah kerusakan, dan senantiasa bekerjasama sesama umat manusia untuk mewujudkan masyarakat adil, makmur dan sejahtera lahir dan batin. Selain itu, juga harus senantiasa bersikap kasih sayang, bertanggungjawan dan melakukan amar ma'ruf dan nabi munkar, berlomba melakukan kebajikan guna mewujudkan masyarakat Islam yang sebenarnya. ${ }^{60}$

Selain itu, kegiatan sosial keagamaan Muhammadiyah juga diwujudkan melalui berbagai amal usah, seperti rumah sakit, panti asuhan, rumah singgah dan sebagainya. ${ }^{61}$ Kegiatan sosial keagamaan didukung oleh beberapa lembaga semi otonom seperti Aisyiyah, Nasyiatul 'Aisyizab (NA), Pemuda Muhammadiyah, Ikatan Remaja Muhammadiyah (IRM) /Ikatan Pelajar Muhammadiyah (IPM), Ikatan Mahasiswa Muhamadiyyah (IMM), Tapak Suci Putra Muhamadiyah, Gerakan Kepanduan Hiø̧bul-Wathan (HW), ${ }^{62}$ dan sebagainya.

${ }^{60}$ Bandarsyah, D. (2016). Dinamika Tajdid Dalam Dakwah Muhammadiyah. HISTORIA: Jurnal Program Studi Pendidikan Sejarah, 4(2), 67-74.

${ }^{61}$ Alfian, M. A. (2016). Muhammadiyah dan Agenda Gerakan untuk Indonesia yang Beradab. Jurnal Muhammadiyah Studies, 1(1), 44-55.

${ }^{62}$ Pimpinan Pusat Muhammadiyah. hlm. 6 


\section{Penutup}

Berdasarkan uraikan di atas dapat ditarik beberapa kesimpuan, diantaranya adalah :

1. Muhammadiyah memiliki kiprah sangat penting dalam pembaharuan pendidikan di Indonesia. Pendidikan yang dilaksanakan oleh Muhammadiyah bersifat modern-theosentris. Artinya dalam pembaharuan pendidikan, Muhammadiyah mengakomodasi pendidikan Barat yang bersifat positif dengan tetap mendudukkan wahyu dan sunnah Rasul sebagai acuannya.

2. Dalam bidang sosial keagamaan prinsip dasarnya adalah berlomba dalam melakukan kebaikan. Untuk mewujudkan hal itu, Muhammadiyah mendirikan berbagai lembaha sosial keagamaan, seperti panti asuhan, rumah singgah, rumah sakit, kelompok pengajian dan sebagainya.

\section{Bibliography}

Abidin, Z. Menapaki Distingsi Geneologis Pemikiran Pendidikan (Muhammadiyah Dan Nahdlatul Ulama) Zainal Abidin Sekolah Tinggi Agama Islam Negeri (Stain) Jurai Siwo Metro. Nið̧am Journal of Islamic Studies, 4(2), 2015

Abuddin Nata (ed), Sejarah Pertumbuhan dan Perkembangan Lembaga-Lembaga Pendidikan Islam di Indonesia, Jakarta: Gramedia, 2016.

Afifuddin, Sejarab Pendidikan, Bandung: Prosfect, 2017.

Ahmad Mansur Suryanegara, Api Sejarah, Bandung: Salamadina, 2010.

Alfian, Muhammadiyah dan Agenda Gerakan untuk Indonesia yang Beradab. Jurnal Muhammadiyah Studies, 1(1), 2016.

Arlen, D., Sudjarwo, S., \& Sinaga, R. M, "Pemikiran Kh. Ahmad Dahlan dalam Bidang Sosial dan Pendidikan," Jurnal Studi Sosial 2(4) (2014).

Azumardi Azra, Pendidikan Islam: Tradisi dan Moderniasai di Tengab Melinim III Jakarta: UIN Press, 2012. 
20 | Belajea: Jurnal Pendidikan Islam, Vol. 5, No. 01, 2020

Bandarsyah, D. Dinamika Tajdid Dalam Dakwah Muhammadiyah. HISTORLA: Jurnal Program Studi Pendidikan Sejarah, 4(2), 2016

Basinun, B. Modernisasi Pendidikan Islam Di Indonesia: Respon Muhammadiyah Terhadap Model Pendidikan Barat. At-Ta'lim: Media Informasi Pendidikan Islam, 16(2), 2018.

Deliar Noer, Gerakan Moderen Islam di Indonesia 1900-1942 Jakarta: LP3ES, 2014.

Enung Rukiati dan Hikmawati Feti, Sejarah Pendidikan Islam di Indonesia (Bandung: Pustaka Setia, 2016.

FITRIANAH, S. Kiprah Mubammadiyah Terbadap Pendidikannya Di Gresik Tabun 1926-1942 (Doctoral Dissertation, UNIVERSITAS AIRLANGGA). 2015.

Huda, S, “Teologi Mustad'afin di Indonesia: Kajian atas Teologi Muhammadiyah," TSAQAFAH 7(2), 2011.

Karel A. Steenbrink, Pesantren, Madrasah, Sekolab: Pendidikan Islam dalam Kurun Moderen, Jakarta: LP3ES, 1994.

Lenggono, W. Lembaga Pendidikan Muhammadiyah (Telaah Pemikiran KH Ahmad Dahlan tentang Pembaruan Pendidikan Islam di Indonesia). Islamadina: Jurnal Pemikiran Islam, 19(1), 2018.

M. Dawam Raharjo, Intelektual Intelegensia dan Perilaku Politik Bangsa: Risalah Cendikiawan Muslim, Bandung: Mizan, 2016.

Maunah, H. B. Sejarah pemikiran dan tokoh modernisme Islam. Jakarta: PT. Raja Grafindo Persada, 2016.

Mayarisa, D. Konsep Integrasi Pendidikan Islam Dalam Perspektif Pemikiran Kh. Ahmad Dahlan. Fitra, 2(1). 2018.

Muhammad Syamsu As, Ulama Pembawa Islam di Indonesia dan Sekitarnya Jakarta: Lentera, 2017. 
Mustapa, L. "Pembaruan Pendidikan Islam: Studi atas Teologi Sosial Pemikiran KH Ahmad Dahlan. Jurnal Ilmiah AL-Jauhari," Jurnal Ilmiah AL-Jauhari: Jurnal Studi Islam dan Interdisipliner 2(1).2017.

Musthafa Kamal Pasha dan Ahmad Adaby Darban, Muhammadiyah sebagai Gerakan Islam, Yogyakarta: LIPPI UMY, 2002.

Muttaqin, A. Pemikiran pembaharuan Pendidikan Islam: Studi komparasi atas pemikiran KH. Hasyim Asy'ari dan KH. Ahmad Dablan, implementasinya dalam Pendidikan Islam di Era Global (Doctoral dissertation, Universitas Islam Negeri Maulana Malik Ibrahim). 2017.

Nuris, A. Ahmad Dahlan Dan Pesantren: Gerakan Pembaharuan Pendidikan, Dakwah, Dan Pemberdayaan Masyarakat Di Indonesia. Dirosat: Journal of Islamic Studies, 1(2), 2017.

Pimpinan Pusat Muhammadiyah, Pedoman Hidup Islami Muhammadiyah (Keputusan Mukbtamar Muhammadiyah ke-44 tahun 2000 di Jakarta, Jakarta: Suara Muhammadiyah, 2012.

Rahem, Z, "Gerakan Progressif Muhammadiyah dan Nahdlatul Ulama Menjaga Marwah Pendidikan Keislaman di Nusantara," Al Hikmab: Jurnal Studi Keislaman 9(1). 2017.

Ramayulis, Sejarab Pendidikan Islam: Napaktilas Pembaharuan Konsep, Filsafat dan Metodologi Pendidikan Islam dari Era Nabi SAW sampai Ulama Nusantara, Jakarta: Kalam Mulia, 2016.

Said Tuhuleley (ed), Reformasi Pendidikan Mubammadiyah Suatu Keniscayaan, Yogyakarta: SM, 2016.

Samsul Nizar dan Ramanyulis, Filsafat Pendidikan Islam, Jakarta: Kalam Mulia, 2016.

Slamet Abdullah \& Muslich KS, Se-Abad Muhammadiyah, dalam Pergumulan Budaya Nusantara, Yogyakarta: Global Pustaka Utama, 2010. 
22 | Belajea: Jurnal Pendidikan Islam, Vol. 5, No. 01, 2020

Stepu, S. B. Pemikiran teologi KH Abmad Dablan (Doctoral dissertation, Universitas Islam Negeri Sumatera Utara). 2016

Susiyani, A. S. Manajemen Boarding School dan Relevansinya dengan Tujuan Pendidikan Islam di Muhammadiyah Boarding School (MBS) Yogyakarta. Jurnal pendidikan madrasah, 2(2), 2017.

Syaifuddin, M. A., Anggraeni, H., Khotimah, P. C., \& Mahfud, C.. Sejarah Sosial Pendidikan Islam Modern Di Muhammadiyah. Tadarus, 8(1). 2019

Syarif, U. Gerakan Pembaruan Pendidikan Islam: Studi Komparasi Pergerakan Islam Indonesia Antara Syekh Ahmad Surkatiy dan Kh Ahmad Dahlan. Reflektika, 12(1), 2017.

Yusra, N. Muhammadiyah: Gerakan Pembaharuan Pendidikan Islam. POTENSIA: Jurnal Kependidikan Islam, 4(1), 2018. 